\title{
Long-Lasting Effects of GABA Infusion into the Cerebral Cortex of the Rat
}

\author{
Teresa Montiel, ${ }^{\dagger}$ Daniel Almeida, Iván Arango, Eduardo Calixto, \\ César Casasola and Simón Brailowsky \\ Departamento de Neurociencias, Instituto de Fisiología Celular, Universidad Nacional \\ Autónoma de México (U.N.A.M.), México
}

\section{SUMMARY}

In electrophysiological terms, experimental models of durable information storage in the brain include long-term potentiation (LTP), long-term depression, and kindling. Protein synthesis correlates with these enduring processes. We propose a fourth example of long-lasting information storage in the brain, which we call the GABA-withdrawal syndrome (GWS). In rats, withdrawal of a chronic intracortical infusion of GABA, a ubiquitous inhibitory neurotransmitter, induced epileptogenesis at the infusion site. This overt GWS lasted for days. Anisomycin, a protein synthesis inhibitor, prevented the appearance of GWS in vivo. Hippocampal and neocortical slices showed a similar post-GABA hyperexcitability in vitro and an enhanced susceptibility to LTP induction. One to four months after the epileptic behavior disappeared, systemic administration of a subconvulsant dose of pentylenetetrazol produced the reappearance of paroxysmal activity. The long-lasting effects of tonic $\mathrm{GABA}_{\mathrm{A}}$ receptor stimulation may be involved in long-term information storage processes at the cortical level, whereas the cessation of $\mathrm{GABA}_{\mathrm{A}}$ receptor stimulation may be involved

\footnotetext{
${ }^{\dagger}$ Corresponding author:

Apdo. Postal 70-253, México 04510 D.F., MEXICO

tel: +(525) 622-5761; fax: +(525) 622-5607

e-mail: tmontiel@ifisiol.unam.mx
}

in chronic pathological conditions, such as epilepsy. Furthermore, we propose that GWS may represent a common key factor in the addiction to GABAergic agents (for example, barbiturates, benzodiazepines, and ethanol). GWS represents a novel form of neurono-glial plasticity. The mechanisms of this phenomenon remain to be understood.

\section{KEYWORDS}

Focal epilepsy, GABA-withdrawal syndrome, GWS, memory, motor cortex, GFAP, plasticity

\section{INTRODUCTION}

Over the past few years, we have been involved in studies addressing GABA-mediated inhibition in several different models of epilepsy. In photo-sensitive baboons and in kindled rats, we have demonstrated that intracortically applied GABA has powerful anticonvulsant effects (Fukuda, 1987; Brailowsky, 1989). In all cases, we observed that cessation of GABA infusion was associated with the appearance of epileptogenic activity at the site of the GABA infusion (Brailowsky, 1987). Phenomenologically, we named this event the "GABA-withdrawal syndrome (GWS)".

Although originally described in the baboon, GWS was also induced in the rat somatomotor cortex (Brailowsky, 1988), hippocampus, and amygdala (Le Gal la Salle, 1988). We also showed, using a 100 
$\mu \mathrm{g} / \mu \mathrm{L} / \mathrm{h}$ dose, an inverse relation between GABA infusion time (from $6 \mathrm{~h}$ to $2 \mathrm{wk}$ ) and the latency and duration of epileptogenic activity (Brailowsky, 1988). With this procedure, a 3-h infusion of GABA was not effective in inducing GWS. We later found that hippocampal slices, perfused with GABA for 120 min, show an enhanced response to electrical stimulation and decreased paired-pulse during the washing period, GABA-mediated inhibition (GarciaUgalde, 1992).
Searching for neurotransmitter receptor specificity and for the minimum time of continuous GABA infusion that is required for inducing GWS, we produced a long-lasting GWS after a relatively short intracortical infusion of either GABA or $\mathrm{GABA}_{\mathrm{A}}$ agonist. The absence of an effect using antagonists of the excitatory neurotransmitter glutamate further suggests that the GWS phenomenon is mainly dependent, at least in the first stages, on changes in inhibitory mechanisms.

TABLE 1

Occurrence of epileptogenic EEG activity ${ }^{1}$ consecutive to intracortical microinfusion of various agents.

\begin{tabular}{|c|c|c|c|c|c|}
\hline Drug & Dose & $\begin{array}{l}\text { Infusion time } \\
(\min )^{2}\end{array}$ & $\begin{array}{c}\% \text { GWS } \\
(\mathrm{n})\end{array}$ & $\begin{array}{c}\text { Latency } \\
(\min )\end{array}$ & $\begin{array}{c}\text { Duration } \\
\text { (day's) }\end{array}$ \\
\hline GABA & $\begin{array}{c}50 \mathrm{mM} \\
100 \mathrm{mM} \\
500 \mathrm{mM} \\
" \\
" \\
"\end{array}$ & $\begin{array}{r}120 \\
120 \\
120 \\
60 \\
30 \\
15\end{array}$ & $\begin{array}{r}76.9(13) \\
100(11) \\
100(9) \\
84.6(13) \\
58.3(12) \\
0(8)\end{array}$ & $\begin{array}{r}35.2 \pm 3.4 \\
39.9 \pm 6.5 \\
95.4 \pm 10.2 \\
115.0 \pm 7.1 \\
99.7 \pm 11.8 \\
\end{array}$ & $\begin{array}{r}2.2 \pm 0.4 \\
3.3 \pm 0.5 \\
7.0 \pm 0.4 \\
3.27 \pm 0.9 \\
7.0 \pm 2.0 \\
\end{array}$ \\
\hline $\begin{array}{l}\text { Aniso -> } \\
\text { GABA+Aniso. }\end{array}$ & $\begin{array}{c}75 \mathrm{mM}->+ \\
0.5 \mathrm{M} \\
\end{array}$ & $60->120$ & $0(4)$ & - & - \\
\hline Aniso + GABA & $\begin{array}{l}75 \mathrm{mM}+ \\
0.5 \mathrm{M}\end{array}$ & 120 & $0(4)$ & - & - \\
\hline Isoguvacine & $\begin{array}{c}61 \mathrm{mM} \\
" \\
"\end{array}$ & $\begin{array}{c}120^{*} \\
15^{*} \\
2^{*} \\
\end{array}$ & $\begin{array}{l}100(7) \\
100(2) \\
100(7)\end{array}$ & $\begin{array}{c}127.8 \pm 39.9 \\
158.5 \pm \\
232.5 \pm 13.3\end{array}$ & $\begin{array}{c}11.42 \pm 0.6 \\
6.5 \pm \\
5.0 \pm 0.6\end{array}$ \\
\hline THIP & $\begin{array}{r}10 \mathrm{mM} \\
1 \mathrm{mM} \\
100 \mu \mathrm{M} \\
10 \mathrm{mM} \\
1 \mathrm{mM} \\
100 \mu \mathrm{M} \\
\end{array}$ & $\begin{array}{c}120^{*} \\
120^{*} \\
120 \\
2^{*} \\
2^{*} \\
2 \\
\end{array}$ & $\begin{array}{c}100(8) \\
0(5) \\
0(2) \\
0(4) \\
0(4) \\
0(2) \\
\end{array}$ & $\begin{array}{c}98.6 \pm 7.7 \\
- \\
- \\
- \\
-\end{array}$ & $\begin{array}{c}1.5 \pm 0.5 \\
- \\
- \\
- \\
-\end{array}$ \\
\hline GABA -> APH & $\begin{array}{c}0.5 \mathrm{M}-> \\
444 \mathrm{mM}\end{array}$ & 120,180 & $(5)$ & $100 \pm 22.7$ & $6.0 \pm 1.8$ \\
\hline GABA -> CNQX & $\begin{array}{c}0.5 \mathrm{M}-> \\
100 \mu \mathrm{M}\end{array}$ & 120,180 & (8) & $98.8 \pm 11.3$ & $2.8 \pm 0.9$ \\
\hline Glycine & $0.5 \mathrm{M}$ & $\begin{array}{c}7 \text { days } \\
120\end{array}$ & $\begin{array}{l}0(4) \\
0(4)\end{array}$ & - & - \\
\hline
\end{tabular}

${ }^{1}$ percent of subjects

${ }^{2}$ All infusions, except the acute $(0.4 \mu \mathrm{L}$ in $2 \mathrm{~min})$ infusion, were performed at a rate of $3 \mu \mathrm{L} / \mathrm{h}$. Latency (in min) and duration (in days) of GWS are indicated (mean \pm s.e.m.). Aniso = anisomycin; The antibiotic was given either before and/or with GABA. $*=$ doses that induced EEG slowing during drug infusion. Other abbreviations are given in the text. 


\section{EXPERIMENTAL METHODS}

Experiments were performed in male Wistar rats (200 to $250 \mathrm{~g})$, prepared for chronic recording and intracortical infusion (Brailowsky, 1988). One week after surgery, saline or pharmacological agents (listed in Table 1) were unilaterally applied into the cortex for various periods of time. In separate groups of animals, immediately after GABA or saline disconnection, the respective NMDA and AMPA/quisqualate receptor antagonists, $444 \mathrm{mM}$ APH (aminophosphonoheptanoate) and $100 \mu \mathrm{M}$ CNQX (6-cyano7-nitrouinoxaline-2,3-dione), were administered locally at $1 \mu \mathrm{L} / \mathrm{h}$ for $180 \mathrm{~min}$. All drug and saline solutions contained $0.2 \mathrm{mg} / \mathrm{mL}$ of direct blue to mark the infusion site and the diffusion area. The rats were sacrificed either $10 \mathrm{~d}$ after the electrical signs of GWS had disappeared or 30 to $120 \mathrm{~d}$ after overt GWS had disappeared, but with the administration of PTZ or its vehicle (saline) before the sacrifice (see below). The brains were processed for Nissl staining and for glial fibrillary acidic protein (GFAP) immunohistochemistry (Hsu, 1981).

\section{RESULTS}

In all animals in which GABA was successfully infused, except those of the 15-min infusion group, GWS was observed (Table 1). The $\mathrm{GABA}_{\mathrm{A}}$ agonists

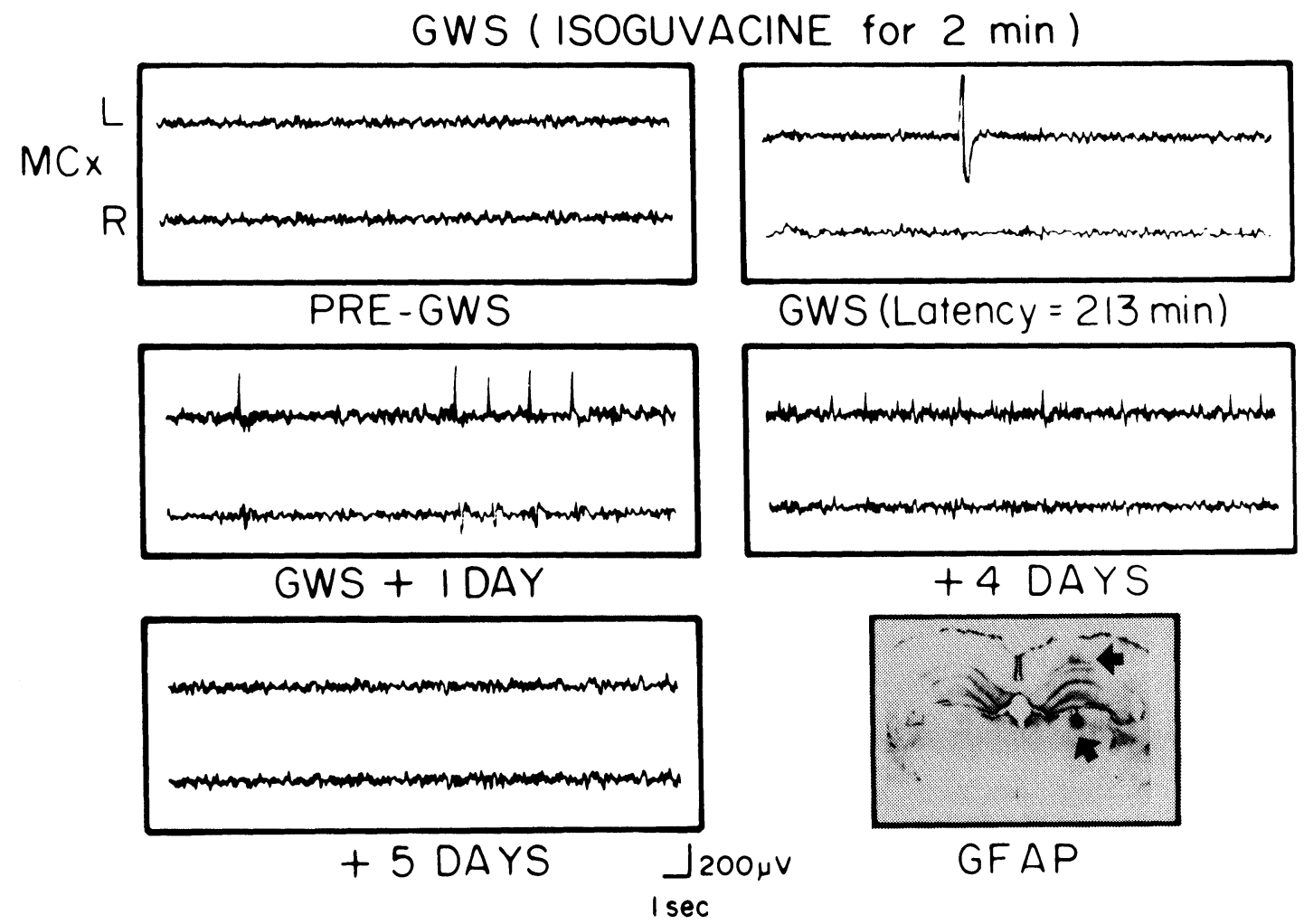

Fig. 1: An example of a GWS-like syndrome induced by acute, intracortically administered isoguvacine, a specific $\mathrm{GABA}_{\mathrm{A}}$ agonist, into the left somatomotor cortex. The latency for the appearance of the first epileptic spike was 213 min after injection. Insert: Micrograph of a coronal section of the rat brain processed for glialfibrillary acidic protein (GFAP) immunoreactivity. Note the astrocytic reaction in the GABA-infused side, both at the cortical site and in ipsilateral thalamic structures (arrows). 
used, isoguvacine and THIP, induced GWS with electrographic features similar to those induced by GABA (Table 1). It is noteworthy that acute microinjections of isoguvacine $(2 \mathrm{~min})$ were effective in inducing paroxysmal activity for $5 \mathrm{~d}$ or more (see Table 1 and Fig. 1).

Histological analysis showed an area of gliosis at the cortical infusion site and in the thalamic projection site, in particular on the upper portion of the ventrolateral (VL) and posterior groups, and in the reticular nucleus (Fig. 1). GWS induction was not prevented by either APH or CNQX, which when given alone, had no effect.

Intracortical administration of glycine produced neither a behavioral nor an EEG abnormality in the 200-min follow-up period after drug infusion. Sixty to 120 days after the electrical signs of GWS disappeared, rats were injected systemically with a subconvulsant dose (20 to $25 \mathrm{mg} / \mathrm{kg}$ i.p.) of PTZ, a widely used epileptogenic agent (Dedeyn, 1992), or with the PTZ vehicle (saline). In 12 of 14 rats, PTZ induced the reappearance of localized, highvoltage paroxysmal activity at the GABA-infused site, similar to the previous GWS and lasting from 60 to $90 \mathrm{~min}$ (Fig. 2).

In search of a possible relation between the in vitro analog of GWS and in vitro long-term potentiation (LTP) (Bliss, 1993), we treated cortical slices with GABA, applying the same methods as

GWS (GABA $2 \mathrm{~h}$ )

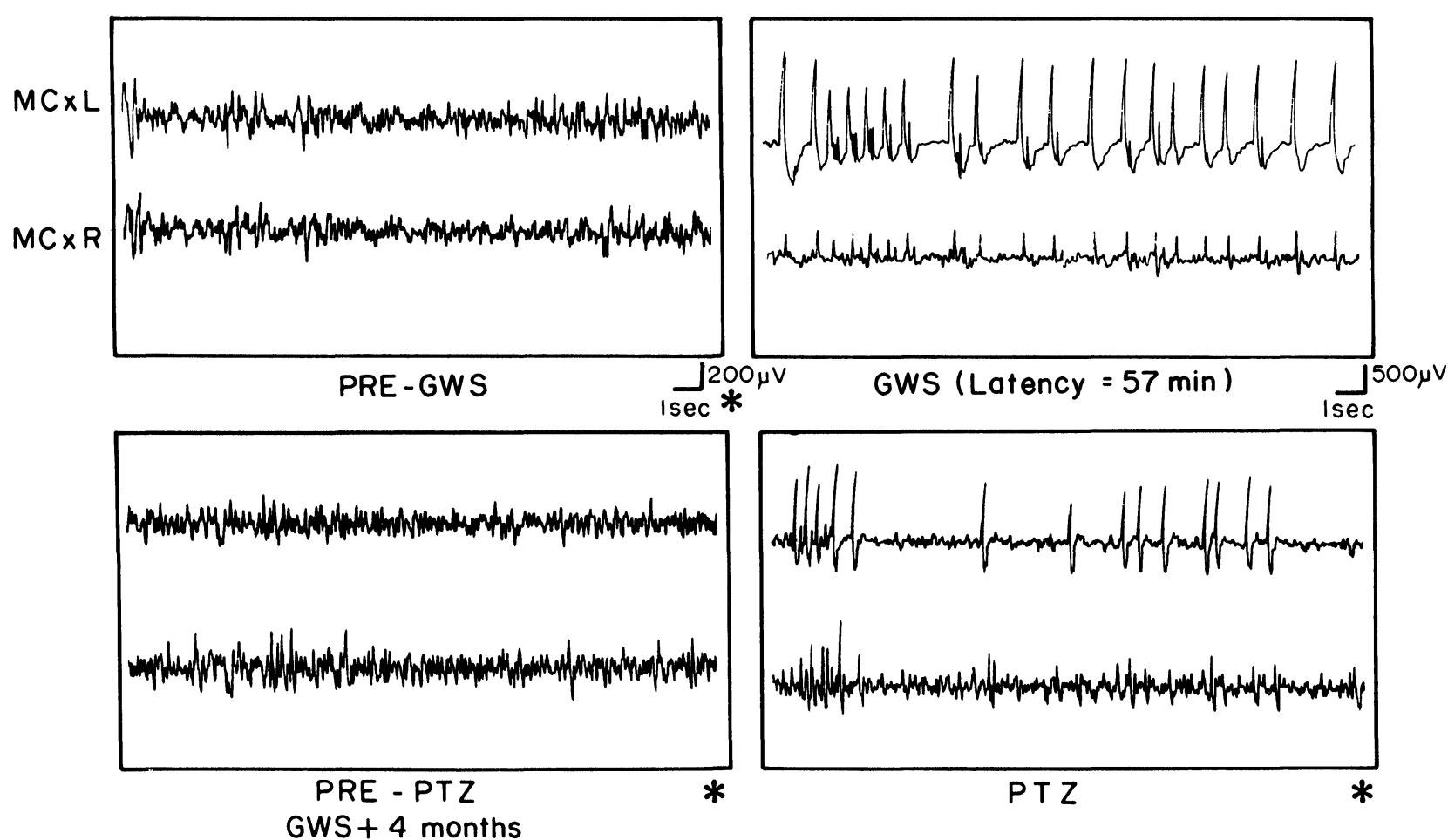

Fig. 2: An example of the electrographic changes typical of a GWS induced after 120 min of continuous intracortical GABA infusion. GABA was applied into the left somatomotor cortex (MCx). The effects of i.p. injection of pentylenetetrazol $(20 \mathrm{mg} / \mathrm{kg}) 4$ months after the disappearance of electrographic signs of GWS epileptogenesis are also shown. Note the reactivation at the cortical focus, with characteristics similar to those observed originally. 
those used with hippocampal slices. We found that (a) cortical slices also show hyperexcitability after GABA incubation (Fig. 3), and (b) electrical stimulation that failed to produce LTP $(40 \mathrm{~Hz}, 200$ $\mathrm{ms} \times 10$, at $0.2 \mathrm{~Hz})$ in control slices $(\mathrm{n}=3)$ elicited a further enhancement of the already facilitated response in GWS slices $(n=4)$ and most notably, the appearance of additional components.

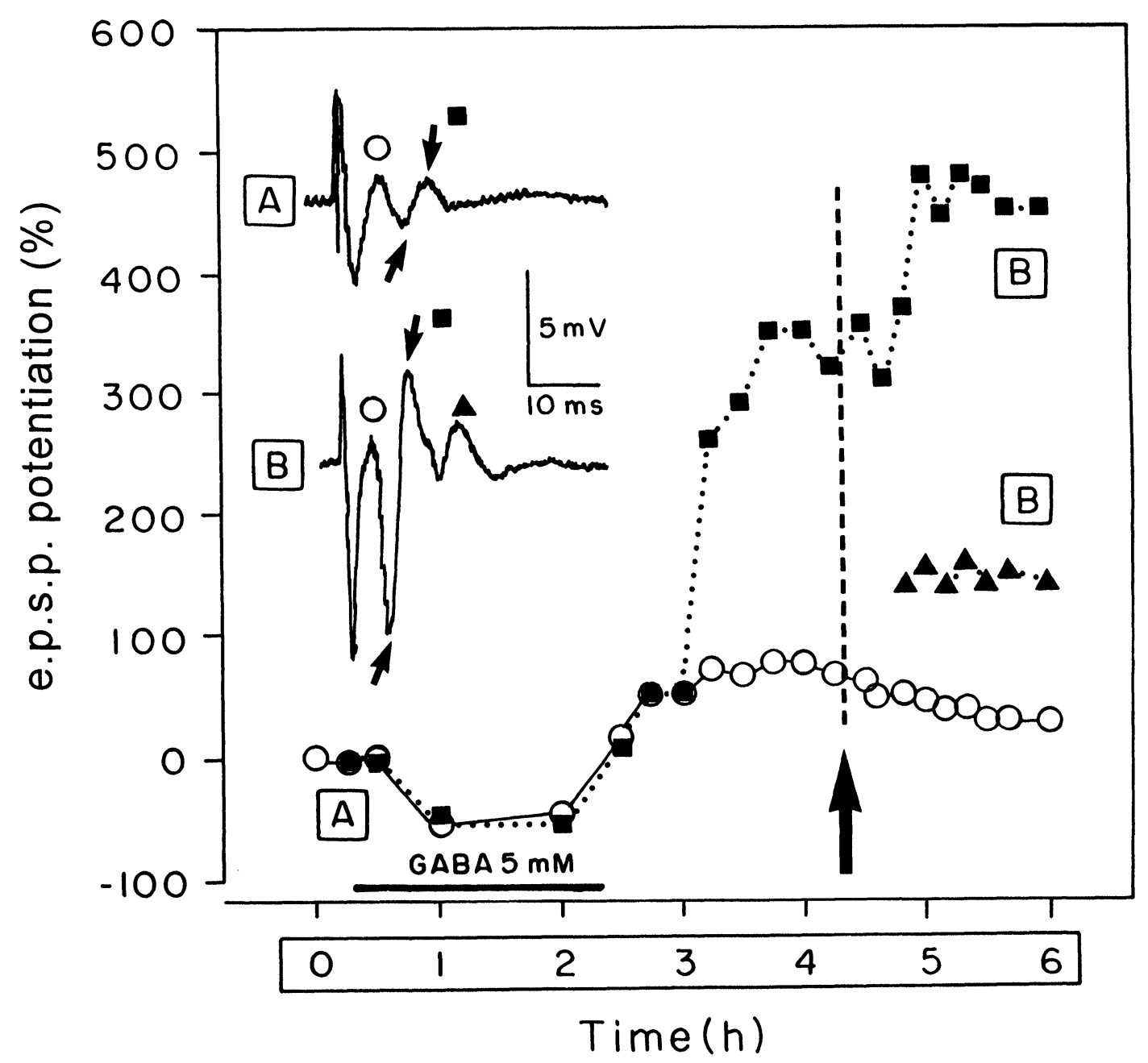

Fig. 3: In vitro induction of cortical GWS and the effects of electrical stimulation. Longitudinal brain slices (400 $\mu \mathrm{m})$, obtained from anesthetized young adult (150 g) Wistar rats, were incubated for 60 min in Ringer-Krebs solution and then for $120 \mathrm{~min}$ in $5 \mathrm{mM} \mathrm{GABA}$, followed by a wash. The graph plots the slope of the rising phase of the various components (indicated by symbols) of the population evoked response (e.p.s.p.), recorded from the superficial layers (I-II) of the cortex in response to test stimuli applied to the deep (V-VI) cortical layers. Each point represents the average of 10 responses. The first response is shown in empty circles, the second component, indicated by arrows, is illustrated with filled squares, and in triangles, a late component that appeared after GWS induction and electrical stimulation ( $40 \mathrm{~Hz}$ for $200 \mathrm{~ms} \times 10$, at $0.2 \mathrm{~Hz}$ ). (A) control response; (B) response after GWS induction and electrical stimulation. Note that GABA incubation produced an inhibition of the e.p.s.p. response, followed by a facilitation of about $350 \%$. Electrical stimulation, applied at the arrow, produced a further enhancement of the response of about $100 \%$ and the appearance of an additional component (filled triangle) in the response. Calibration: $5 \mathrm{mV}, 10 \mathrm{~ms}$. 


\section{DISCUSSION}

Both the qualitative and quantitative features of the GWS found in this study are comparable to those previously observed (Brailowsky, 1988) in rats, in which a 6-h GABA infusion time was $\mu \mathrm{L} / \mathrm{h}$. It is thus possible that by increasing the infusion rate, we obtained a larger GABA diffusion and, therefore, a larger population of affected cells; alternatively, a saturation of GABA transport or turnover processes, or both may have occurred.

Among the $\mathrm{GABA}_{\mathrm{A}}$ agonists, the quantitative differences in GWS may be related to their pharmacokinetic profiles: isoguvacine remains longer in the extracellular space because it is not taken up, whereas THIP is known for its short duration of action (Krogsgaard-Larsen, 1994). This distinction may explain why an acute microinjection of isoguvacine was as effective as a 30 min GABA infusion.

The specificity of the effects of GABA is supported by

a) the lack of abnormalities observed after the cessation of glycine infusion;

b) the effects of specific $\mathrm{GABA}_{\mathrm{A}}$ agonists (this study), and

c) the potentiation of GWS produced by the neurosteroid allopregnanolone, an allosteric modulator of the $\mathrm{GABA}_{\mathrm{A}}$ receptor (Calixto, 1995).

The participation of $\mathrm{GABA}_{\mathrm{B}}$ receptors in the induction of GWS can be excluded because baclofen does not produce withdrawal signs (on the contrary, the drug itself induces paroxysmal activity). In addition, the specific $\mathrm{GABA}_{\mathrm{B}}$ antagonists, phaclofen and CGP 35348, do not modify GWS features (Brailowsky, 1995). In addition, GWS was not prevented by the glutamate receptor antagonists APH or CNQX.

In the current study, we also confirmed the histological changes previously reported by Brailowsky (1988), both at the infusion site and in ipsilateral thalamic areas, adding immunohistochemical evidence (GFAP staining) of astrocytic participation in this reaction. The thalamic changes are similar to those reported with cortical epileptogenic foci that were induced with convulsant agents, such as bicuculline or penicillin, and shown to be excitotoxic in nature because they can be prevented by NMDA antagonists (Clifford, 1989). We propose that this event, gliosis, is but one manifestation of many important changes that are occurring in glial function. An explanation of these events will be critical to understanding the mechanisms involved in GWS.

Chronic GABA exposure may induce the creation of some form of "epileptic" $\mathrm{GABA}_{\mathrm{A}}$ receptor or an enhanced vulnerability to seizures, or both. For example, in Angelman syndrome, a clinical condition in which epileptic seizures are frequent, a deletion of genes encoding the $\mathrm{GABA}_{\mathrm{A}}$ receptor subunits, alpha-5, beta-3, and gamma-3, in chromosome 15q11-13, has been reported (Mclean, 1995).

The $\mathrm{GABA}_{\mathrm{A}}$ receptor is a member of the superfamily of ionotropic receptors comprising several subunits, whose combination determines the particular pharmacology reported for diverse brain regions (Olsen, 1990; Macdonald, 1994). This property of allosteric modulation is relevant to widely used and clinically important drugs, such as the benzodiazepines, barbiturates, neurosteroids, and ethanol. After chronic administration, all these drugs, except the neurosteroids, can induce physical dependence and withdrawal signs. A common neurochemical mechanism involving GABA function has been suggested for such abstinence symptoms (Cowen, 1982). The premenstrual syndrome has been proposed to be a possible withdrawal syndrome to progesterone, a positive modulator of the $\mathrm{GABA}_{\mathrm{A}}$ receptor (Gallo, 1993). A progesterone metabolite, allopregnanolone, significantly potentiates GWS (Calixto, 1995). Despite the clinical differences in these withdrawal syndromes, an understanding of the pathophysiology of GWS may enable us to decipher the mechanisms responsible for sedative, anxyiolitic, and hypnotic drug addiction, a 
significant epidemiological problem in many countries. In fact, GWS may represent a common key factor in all such addictions.

A fascinating result of this study was the longlasting (months) consequence of a relatively short exposure to $\mathrm{GABA}$ or to $\mathrm{GABA}_{\mathrm{A}}$ agonists (but not to glycine), protracted effects that could be unmasked by the systemic administration of PTZ (but not saline), even 4 months after the apparent disappearance of epileptogenic activity. If we consider such enduring epileptogenic activity as a synaptic expression that is analogous to memory (an "epileptogenic" experience), then a role for GABA in memory processes (conceived as cellular information storage) can be postulated.

A further suggestion for a relation between GWS and information storage derives from our results with anisomycin, an inhibitor of protein synthesis. A wide variety of experimental models, from snails to humans, have demonstrated that when administered from $1 \mathrm{~h}$ before and up to $7 \mathrm{~h}$ after a training or sensitization procedure, antibiotics like anisomycin induce amnesia to the task (Barzilai, 1989; Oleary, 1995). Anisomycin blocks GWS induction and, interestingly, also interferes with drug dependence (Williams, 1994).

The GWS is a remarkable example of synaptic plasticity; its basic mechanism, neuronal and glial, may be analyzed from the rich perspectives offered by studies in epilepsy, drug dependence, and information storage.

\section{ACKNOWLEDGMENTS}

We are grateful for the valuable comments of $\mathrm{R}$ Galambos, T. Bullock, L.R. Squire, J.L. McGaugh, S.P.R. Rose, A. Tobin, R. Olsen, S. Young, M. GarciaMunoz, R. Prado-Alcalá, G. Barrionuevo, M. Segal, and G.R. Siggins. This study was partially supported by grants from DGAPA-UNAM and CONACYT (México).

\section{REFERENCES}

Barzilai A., Kennedy TE, Sweatt JD, Kandel ER. 5HT modulates protein synthesis and the expression of specific proteins during long-term facilitation in Aplysia sensory neurons. Neuron 1989; 2: 1577-1586.

Bliss TVP, Collingridge GL. A synaptic model of memory: long-term potentiation in the hippocampus. Nature 1993; 361: 31-39.

Brailowsky S, Kunimoto M, Menini C, Silva-Barrat C, Riche D, Naquet R. The GABA-withdrawal syndrome: a new model of focal epileptogenesis. Brain Res 1988; 442: 175-179.

Brailowsky S, Menini C, Silva-Barrat C, Naquet R. Epileptogenic $\gamma$-aminobutyric acid-withdrawal syndrome after chronic intracortical infusions in baboons. Neurosci Lett 1987; 74; 75-80.

Brailowsky S, Montiel T, Meneses S, Discala G. Effects of $\mathrm{GABA}(\mathrm{B})$ receptor antagonists on two models of focal epileptogenesis. Brain Res 1995; 702: 126-132.

Brailowsky S, Silva-Barrat C, Menini C, Riche D, Naquet R. Effects of localized chronic GABA infusions into different cortical areas of the photo-sensitive baboon Papio papio. Electroencephalogr Clin Neurophysiol 1989; 72: 147-56.

Calixto E, Montiel T, Lemini C, Brailowsky S. Allopregnanolone potentiates a GABA-withdrawal syndrome in the rat cerebral cortex. Neurosci Lett 1995; 195: 73-76.

Clifford DB, Zorumski CF, Olney JW. Ketamine and MK-801 prevent degeneration of thalamic neurons induced by focal cortical seizures. Exp Neurol 1989; 105: 272-279.

Cowen PJ, Nutt DJ. Abstinence symptoms after withdrawal of tranquilizing drugs: is there a common neurochemical mechanism? Lancet 1982; 360-362.

Dedeyn PP, Dhooge R, Marescau B, Pei YQ. Chemical models of epilepsy with some reference to their applicability in the development of anticonvulsants. Epilepsy Res 1992; 12: 87-110.

Fukuda H, Brailowsky S, Menini C, Silva-Barrat C, Riche D, Naquet R. Anticonvulsant effect of intra-cortical chronic infusions of GABA in kindled rats; focal seizures upon withdrawal. Exp Neurol 1987; 98: 120-129. 
Gallo MA, Smith SS. Progesterone withdrawal decreases latency to and increases duration of electrified prod burial: a possible rat model of PMS anxiety. Pharmacol Biochem Behav 1993; 46: 897-904.

Garcia-Ugalde G, Galarraga E, Bargas J, Brailowsky S. Hyperexcitability of hippocampal CA1 region in brain slices after GABA withdrawal. Neurosci Lett 1992; 147: 229-232.

Hsu SM, Raine L, Fanger H. The use of avidinbiotin-peroxidase complex (ABC) in immunoperoxidase techniques: a comparison between $\mathrm{ABC}$ and unlabeled antibody (PAP) procedures. J Histochem Cytochem 1981; 29: 577-580.

Krogsgaard-Larsen P, Frølund B, Jørgensen FS, Schousboe A. GABA-A receptor agonists partial agonists and antagonists. Design and therapeutic prospects. J Med Chem 1994; 37: 2489-2505.

Le Gal La Salle G, Brailowsky S, Menini C, Naquet R. Local asymptomatic status epilepticus induced by withdrawal of GABA infusion into limbic structures. Exp Neurol 1988; 101: 411-417.

Macdonald RL, Olsen RW. GABA(A) receptor channels. Ann Rev Neurosci 1994; 17 569-602.

Mclean PJ, Farb DH, Russek SJ. Mapping of the alpha(4) subunit gene (GABRA4) to human chromosome 4 defines an (alpha2)-(alpha4)(beta1)-(gamma1) gene cluster: Further evidence that modern $\mathrm{GABA}(\mathrm{A})$ receptor gene clusters are derived from an ancestral cluster. Genomics 1995; 26: 580-586.

Oleary FA, Byrne JH, Cleary LJ. Long-term structural remodeling in Aplysia sensory neurons requires de novo protein synthesis during a critical time period. J Neurosci 1995; 15: 3519-3525.

Olsen RW, Tobin AJ. Molecular biology of GABA A receptors. FASEB J 1990; 4: 1469-1480.

Williams MB, Jope RS. Protein synthesis inhibitors attenuate seizures induced in rats by lithium plus pilocarpine. Exp Neurol 1994; 12: 169-173. 

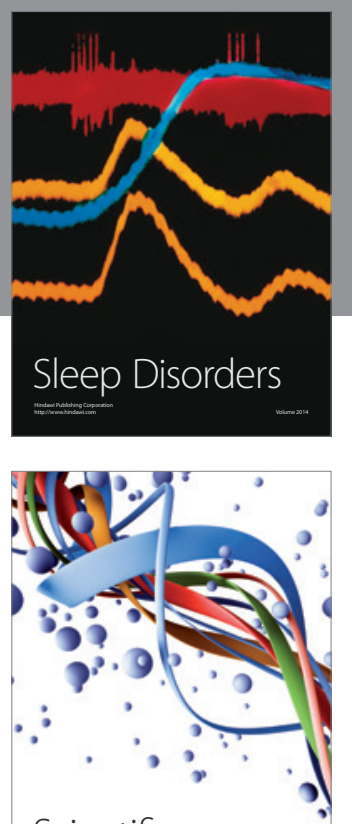

Scientifica
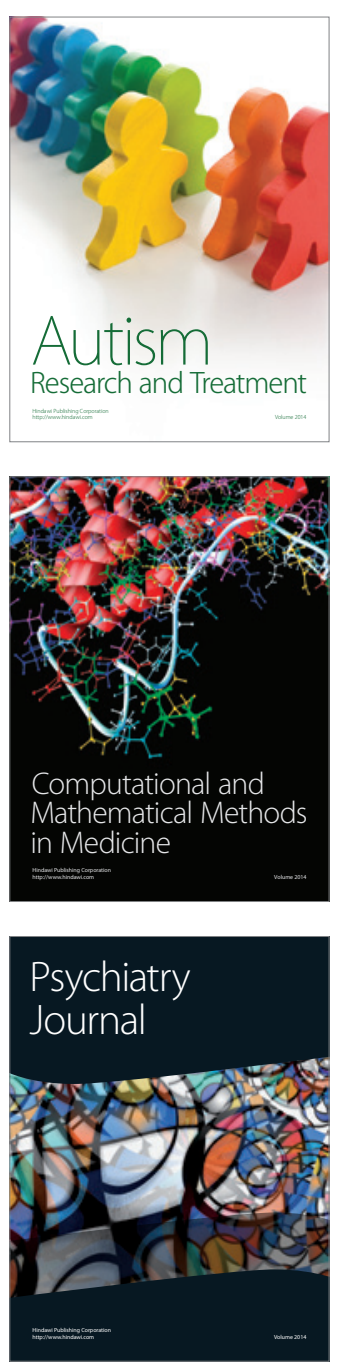
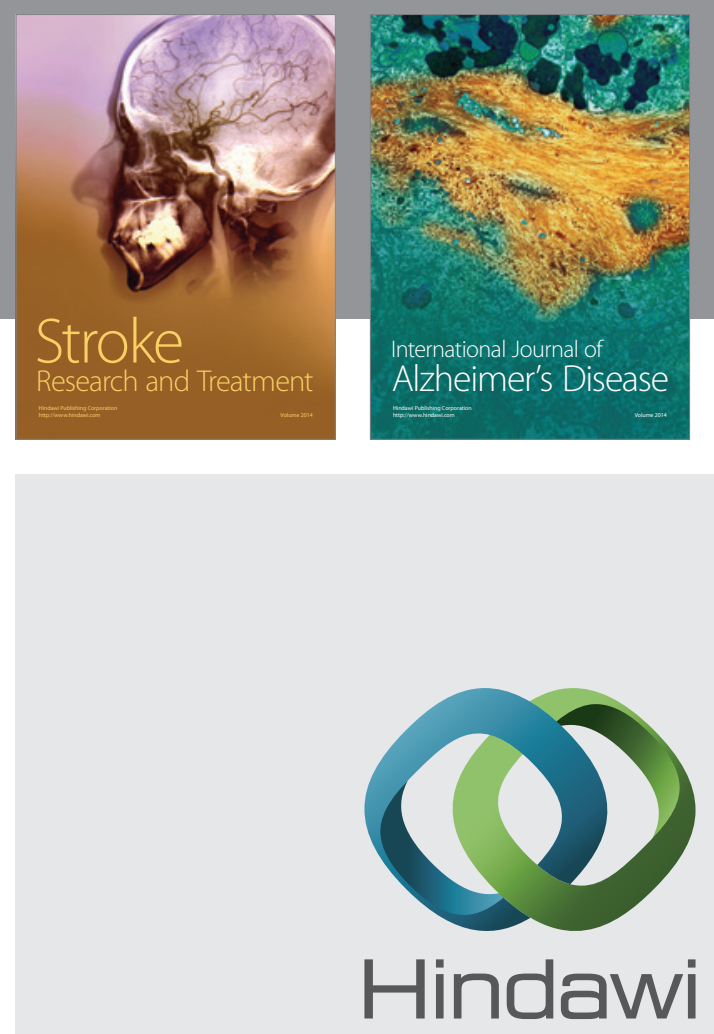

Submit your manuscripts at

http://www.hindawi.com
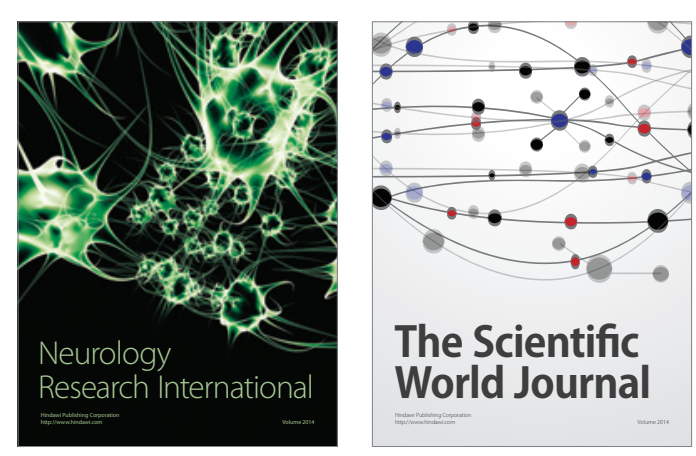

The Scientific World Journal

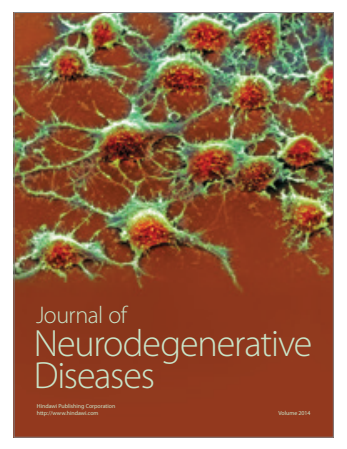

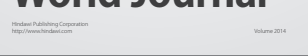

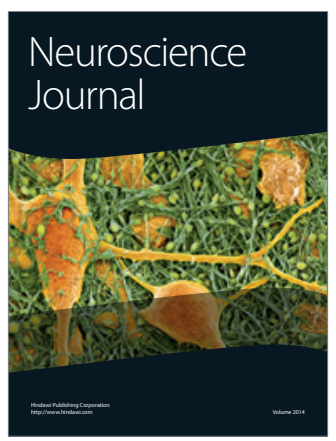

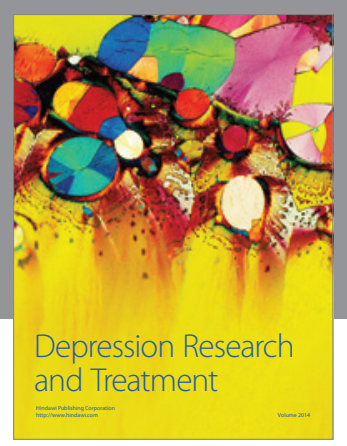
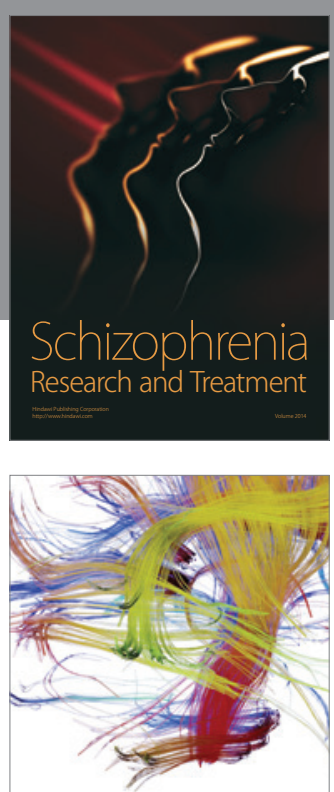

Brain Science

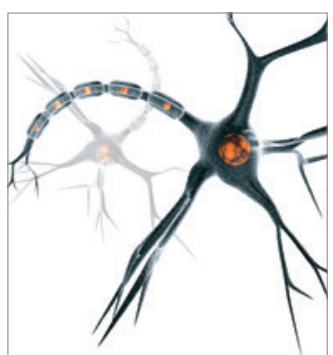

Neural Plasticity
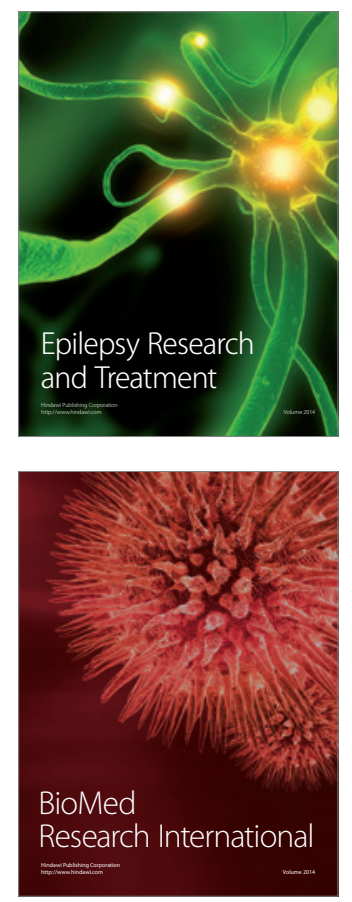

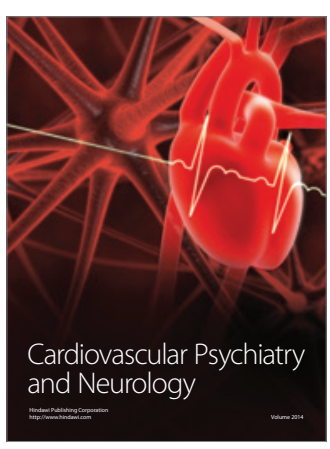

Parkinson's

Disease
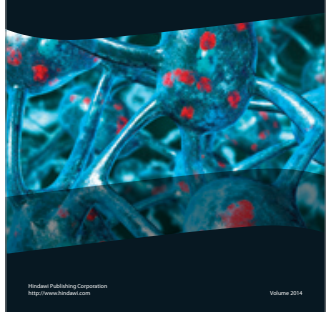